Dmytrochenkova E., Tadlya K.

\title{
SIMULATION OF THE DISTRIBUTION OF AIR FLOWS AND FUEL COMBUSTION PRODUCTS IN A CHANNEL OF A TUNNEL KILN
}

Характерною проблемою роботи тунельних печей з високим перекриттям є вихід продукцї̈ з низькою якістю та зниження енергетичної ефективності прочесу випалу в цілому. Тому об'єктом дослідження обрано прочес протікання пічних газів по каналу тунельної печі, зміна швидкості яких досліджувалась в залежності від геометричних параметрів тунелю.

В ході проведення досліджень залежності розподілення швидкостей потоків пічних газів по каналу печі від ї̈ геометричних характеристик використано метод чисельного моделювання в спрощеній $2 D$ постановиі за допомогою відкритого коду OрепFоат з використанням моделі турбулентності $k$ - $\omega$ переносу напруг зсуву. Отримано поля швидкостей потоків пічних газів для трьох варіантів висоти каналу: базового з висотою склепіння 2 м, зі зниженою висотою склепіння по всій довжині тунелю та зі зниженою висотою тунелю лише в зоні випалу. Аналіз зміни швидкості потоків показав, що найбільш ефективним буде зниження висоти по всій довжині печі, в той час як зміна висоти склепіння в зоні випалу майже не позначиться на рівномірності швидкостей в зоні підігріву. Зниження висоти склепіння так само мінімізує ймовірність виникнення зворотного потоку повітря в зоні охолодження на ділянці від випалу до місия відбору повітря на сушку. Більш низьке перекриття на ділянці охолодження дозволить підвищити інтенсивність відбору теплоти та, відповідно, знизить ї втрати з продукцією, щоб використовувати ї на сушку виробів.

Наведені результати моделювання дають можливість відзначити, що зміна висоти перекриття призведе до збільшення аеродинамічного опору та, відповідно, перепаду тиску. Це потребуватиме додаткових витрат електроенергї на привід тягодуттєвих машин та можливість підвищення температур в просторі під вагонами.

ключові слова: тунельна піч, пічні гази, висота каналу, моделювання розподілення швидкостей, поле швидкостей.

\section{Introduction}

Tunnel kilns ensure the continuity of heat treatment and are widely used in industry from baking bread to burning various brick products. The aerodynamic mode, which is created directly in the kiln tunnel, directly affects the uniformity of the heating of products and contributes to the optimal burning mode in order to obtain high-quality products. Moreover, their relationship, given the direct relationship between the velocity of movement of the coolant (kiln gases) and the rate of the heat transfer process in the cage, is obvious. The lower aerodynamic resistance of the space between the gardens and the ceiling compared to the aerodynamic resistance of the channels of the kiln gardens leads to an uneven volumetric flow rate along the channel of the kiln and, accordingly, to uneven heating of the products. This has a negative effect on both product quality and energy efficiency of heat treatment.

Mainly to solve this problem, measures are taken to intensify heat transfer by mechanical stirring. In particular, in [1-3], with the aim of increasing the convective component of heat transfer between the coolant and the material, it is proposed to install equipment for recirculation in the preheating zone, which will ensure reliable mixing and tur- bulization of the kiln gases over the kiln cross section. And in $[4-6]$, to reduce the unevenness of the heating of the brick cages, it is proposed to use high-velocity burners of the own development of the Gas Institute of the National Academy of Sciences of Ukraine for heating air in the lowtemperature zone. In [7-9], the method of mathematical modeling proved the improvement of heat transfer in the cooling zone of a tunnel kiln when changing the layout of a row of bricks, as well as when using guide vanes. The authors of the study [10] propose improving the temperature parameters of the operation of the tunnel kiln due to the turbine installation located in front of the kiln. And in [11], in order to reduce fuel and electricity consumption during operation of the kiln, it is proposed to lining its active part with high-alumina products based on aluminosilicate fiber.

The authors of the publications cited do not consider the effect of changing the kiln geometry to increase the efficiency of burning products, confirms the relevance of solving the problem of equalizing flow rates in the cage and the space above it. So, the object of research is the process of the flow of kiln gases through the channel of the tunnel kiln, the change in velocity of which is studied depending on the geometric parameters of the tunnel. And the aim of research is to justify a decrease in the height 
of the kiln channel to equalize the flow rates in the cage and the space above it by numerically simulating the movement of kiln gases in the kiln tunnel.

\section{Methods of research}

A tunnel kiln is a long tunnel $(60-200 \mathrm{~m})$ along which a train moves from trolleys loaded with products that are being processed. The scheme of the tunnel kiln is shown in Fig. 1.

The composition of the trolleys is periodically pushed with the help of a pusher. Cold products are loaded into the tunnel, where they are first heated by the heat of the combustion products, then they are fired in the high temperature zone, after which they are cooled by the oncoming air stream and discharged from the kiln. The heat from the products in the cooling zone is used to heat the air. The main part of the heated air is diverted to the needs of drying products, the other part, depending on the design of the kiln, can be used in the process of burning on burners as the primary, or enter the high temperature zone for complete fuel combustion. The exhaust gases are cooled in the zone of heating the processed material of the products to a temperature of $110-200{ }^{\circ} \mathrm{C}$ and are removed by a smoke exhauster into the chimney $[12,13]$.

One of the options for changing the aerodynamic regime in the tunnel is a change in its geometric characteristics, namely a decrease in the height of the tunnel while maintaining the flow rate of the air supplied. Moreover, one should traditionally expect an increase in the kiln gas velocity, which will contribute to a decrease in the temperature difference over the kiln cross section.

The influence of the channel height on the change of kiln gas velocities are considered on the following options:

- basic with a vault height of $2 \mathrm{~m}$;

- with a decrease in the height of the arch along

the entire length of the tunnel (by $25 \mathrm{~cm}$ );

- with a decrease in the height of the tunnel only in the burning zone (by $25 \mathrm{~cm}$ ).

The kiln tunnel is divided into 22 equal sections according to the number of cars. The division scheme is shown in Fig. 1. Between sections 17 and 18 is the air intake for drying.

The distribution of air flows and combustion products is simulated in a simplified $2 \mathrm{D}$ formulation using the OpenFoam open source code using the $k$ - $\omega$ shear stress transfer turbulence model (kOmegaSST) for stationary conditions.

\section{Research results and discussion}

As a result, a velocity distribution is obtained along the kiln channel (Fig. 2). The kiln is divided into three parts, the numbers show the position of the cars along the kiln length.

Obviously, the velocities of air and flue gases increase significantly in the space between the gardens and the arch (in Fig. 2 it is possible to see the effect at the first positions and the air extraction zone for drying - 18 position). This is due both to the redistribution of air, and with the addition of air due to combustion and suction. It also traces the minimization of air velocity in the cooling zone (from 14 to 17 positions) and even more its decrease in the burning zone (9-13 positions).

In the zone of air intake for drying, there is a reverse flow, which is associated with the presence of small gaps inside the garden. The main amount of air moves under the arch and for selection for drying it comes, including from the space through the garden, which causes its reverse movement.

To conduct a comparative analysis of changes in kiln gas velocities and static pressure, a simulation is carried out similar to the base case with identical flow rates, but with a reduction in arch height of $25 \mathrm{~cm}$ along the entire length of the kiln. The simulation results are shown in Fig. 3, 4, where it can be clearly seen that small velocities of kiln gases are observed in the area from the beginning of the cooling zone to the air extraction zone for drying (positions 14-16).

Unlike the previous case, the reverse flow occurs only from the 15th position (Fig. 4), which is explained by the large air flow through the charge.

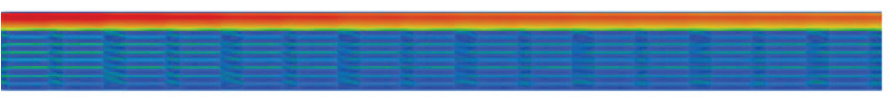

1

7

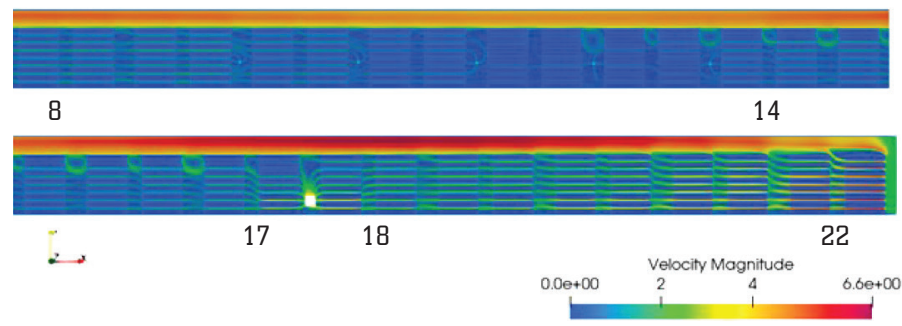

Fig. 2. Distribution of kiln gas flow rates along the kiln channel (basic version)

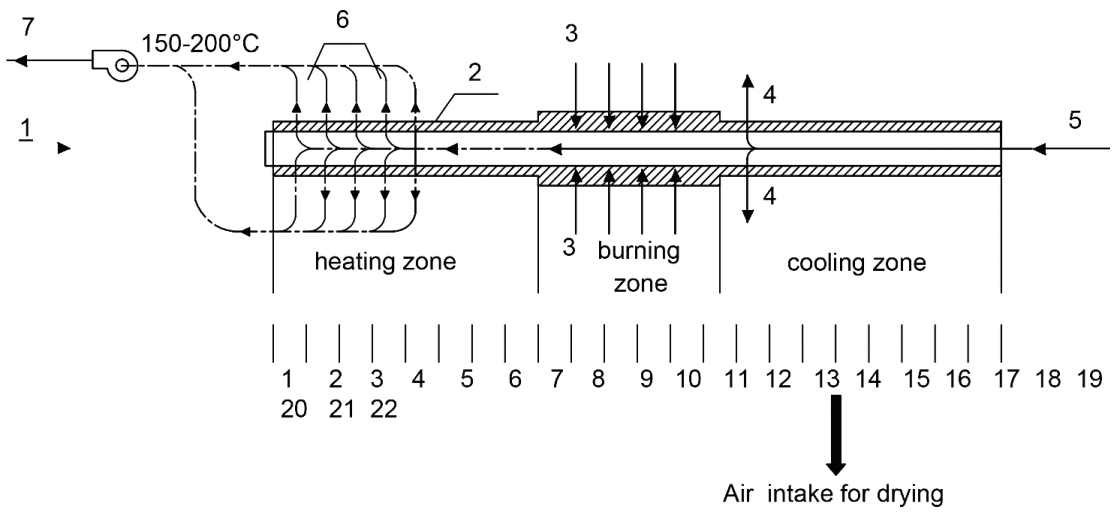

Fig. 1. The scheme of the tunnel kiln: 1 - trolley movement direction; 2 - tunnel; 3 - burners; 4 - discharge of heated air into the burners; 5 - cold air for cooling the burned material; 6 - removal of combustion products; 7 - smoke exhaust 


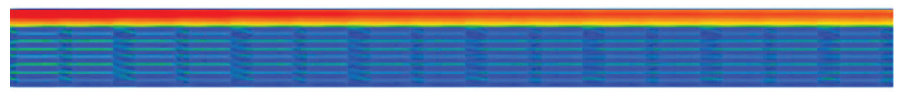

1

7

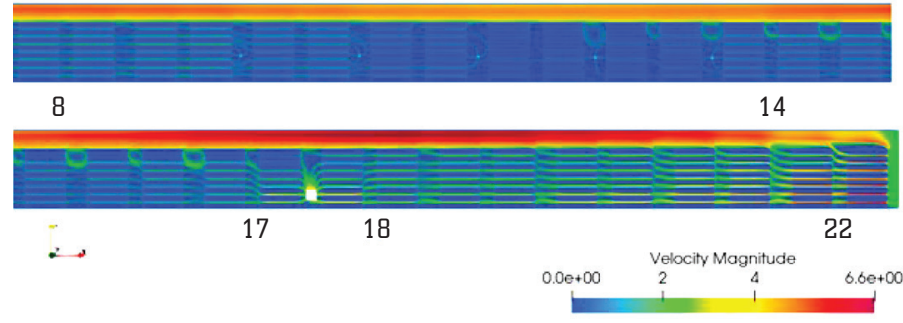

Fig. 3. Velocity field of the kiln gases along the kiln channel with a decrease in the height of the arch by $25 \mathrm{~cm}$ along the entire length of the kiln

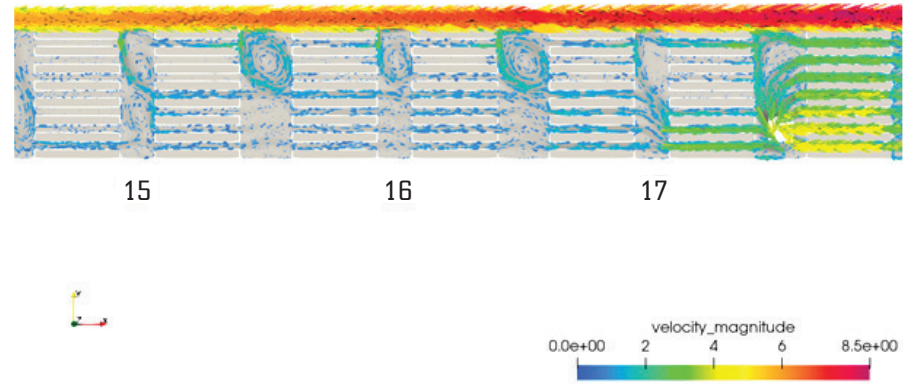

Fig. 4. Velocity distribution in the zone of air intake for drying while reducing the arch height by $25 \mathrm{~cm}$ along the entire kiln length

As a third option for conducting a comparative analysis, it is proposed to consider the dynamics of changes in aerodynamic characteristics. Moreover, as a condition, a reduction in the height of the arch by the same $25 \mathrm{~cm}$ is considered only in the combustion zone (positions 9-14). The flow of air and gases is assumed identical to the base case. The simulation results are shown in Fig. 5.

Fig. 5 shows the total velocity field along the kiln channel. A distinctive feature of the result obtained from that shown in Fig. 2 for the base case, is to increase the velocity in the burning zone from 4.3 to $5.2 \mathrm{~m} / \mathrm{s}$. In other zones, velocity values are approximately the same.

When analyzing the simulation results shown in Fig. 5 and Fig. 2, it should be noted that in options 2 and 3, the values of the maximum velocities in the sub-arch space are higher than the first option. But in the case of a decrease in the arch height along the entire kiln length in this part of it, support for higher velocities is still observed.

In [14], the authors analyze changes in static pressure and velocity of kiln gases along the tunnel height. As a result, the effectiveness of reducing the arch height along the entire kiln length is also proved in comparison with the two other options that were considered.

\section{Conclusions}

The simulation results of the flow velocity of kiln gases along the kiln channel show that the velocity distribution will be more uniform in the case with an overlap reduced by $25 \mathrm{~cm}$. A decrease in the arch height will also minimize the likelihood of a reverse air flow in the cooling zone, and will also contribute to a more complete heat removal from products and, accordingly, will reduce heat loss with products. On the other hand, it is worth noting that a change in the height of the overlap will lead to an increase in aerodynamic drag and, accordingly, a pressure drop. This will require additional energy costs for driving draft engines and the possibility of increasing temperatures in the space under the cars.

The results of these studies will be useful in the reconstruction of existing tunnel kilns in order to improve product quality and increase the energy efficiency of the burning process.

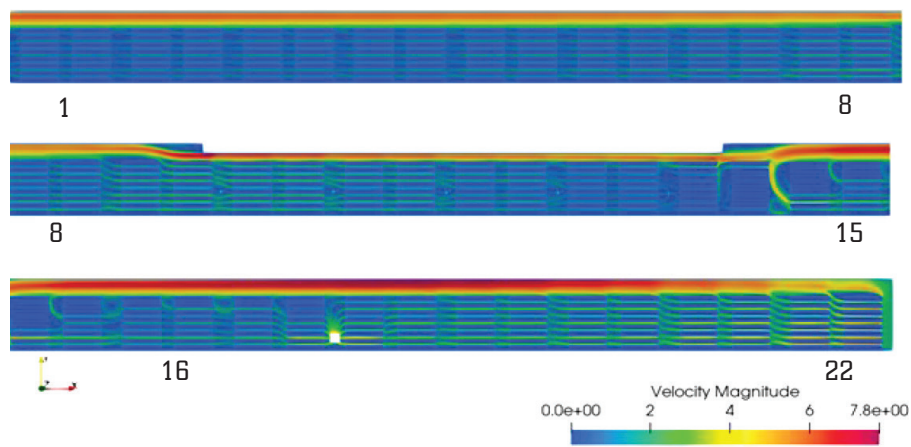

Fig. 5. Total velocity field along the kiln channel 


\section{References}

1. Torchinsky, A. I., Lyashko, A. Yu., Sergienko, A. A., Kryachok, Yu. N (2010). Ceramic Brick Manufacture Tunnel Furnaces Modernization. 1. The Program of the Tunnel Furnaces Modernization Concept and Realization. Energy technologies and resource saving, 1, 72-75.

2. Torchinsky, A. I., Lyashko, A. Yu., Sergienko, A. A., Kryachok, J. N. (2010). Tunnel Furnaces Stock for Ceramic Brick Manufacture Modernization. 2. The Furnaces Heating System Developement. Energy technologies and resource saving, 2, 57-60.

3. Torchinsky, A. I., Lyashko, A. Yu. (2016). Optimization of Thermal and Aerodynamic Operating Mode of Tunnel Kiln for Ceramic Bricks Calcination. Energy technologies and resource saving, 1, 66-72.

4. Pilipenko, R. A., Pilipenko, A. V., Logvinenko, D. M. (2010) Tunnel Kilns for Brick Burning Efficiency Increase. Energy and resource saving, 2, 23-26.

5. Torchinskii, A. I., Sergienko, A. A., Liashko, A. Iu., Kriachok, Iu. N. (2009). Opyt vnedreniia na tunnelnykh pechakh obzhiga keramicheskogo kirpicha energoeffektivnykh skorostnykh gazogorelochnykh ustroistv serii GS. Stroitelnye materialy, izdeliia $i$ santekhnika, 34, 115-119.

6. Torchinskii, A. I., Liashko, A. Iu., Kriachok, Iu. N. (2011). Sopostavitelnye ispytaniia gazogorelochnykh ustroistv serii GS na tunnelnoi pechi obzhiga keramicheskogo kirpicha. Stroitelnye materialy, izdeliia $i$ santekhnika, 3, 16-20.

7. Refaey, H. A., Abdel-Aziz, A. A., Ali, R. K., Abdelrahman, H. E. Salem, M. R. (2017). Augmentation of convective heat transfer in the cooling zone of brick tunnel kiln using guide vanes: An experimental study. International Journal of Thermal Sciences, 122, 172-185. doi: http://doi.org/10.1016/j.ijthermalsci.2017.08.018

8. Abou-Zivan, H. Z. (2004). Convective heat transfer from different brick arrangements in tunnel kilns. Applied Thermal Engineering, 24 (2-3), 171-191. doi: http://doi.org/10.1016/ j.applthermaleng.2003.08.014
9. Refaey, H. A., Abdel-Aziz, A. A., Salem, M. R., Abdelrahman, H. E., Al-Dosoky, M. W. (2018). Thermal performance augmentation in the cooling zone of brick tunnel kiln with two types of guide vanes. International Journal of Thermal Sciences, 130, 264-277. doi: http://doi.org/10.1016/j.ijthermalsci.2018.04.027

10. Shi, H., Ma, L., Liu, M. (2018). Integration Research on Gas Turbine and Tunnel Kiln Combined System. IOP Conference Series: Earth and Environmental Science, 133, 012024. doi: http:// doi.org/10.1088/1755-1315/133/1/012024

11. Zubashchenko, R. V. (2017). The lining of the small capacity tunnel type kiln with the high alumina-silicate fiber refractories. New Refractories, 2, 3-5. doi: http://doi.org/10.17073/ 1683-4518-2017-2-3-5

12. Schukin, A. A. (1973). Promyshlennye pechi i gazovoe khoziaistvo zavodov. Moscow: Energiia, 224.

13. Glinkov, M. A., Glinkov, G. M. (1990). Obschaia teoriia teplovoi raboty pechei. Moscow: Metallurgiia, 223.

14. Dmytrochenkova, E., Tadlya, K. (2019) Analysis of aerodynamic characteristics in the tunnel kiln channel when changing the geometric characteristics of the channel. Innovation solutions in modern science, 6 (33), 37-47.

Dmytrochenkova Ella, PhD, Associate Professor, Department of Heat and Gas Supply and Ventilation, Kyiv Nation University of Construction and Architecture, Ukraine, ORCID: http://orcid.org/ 0000-0003-3768-5245,e-mail: elladmitrochenkova@gmail.com

Tadlya Konstantin, PhD, Technical Director, Kyiv City Innovative Industry Organization of Employers «Center for Resource Efficient and Clean Production», Ukraine, ORCID: http://orcid.org/00000003-1610-0498, e-mail: tkostiantin@gmail.com 